\title{
Transactions of the Royal Historical Society
}

http://journals.cambridge.org/RHT

Additional services for Transactions of the Royal Historical Society :

Email alerts: Click here

Subscriptions: Click here

Commercial reprints: Click here

Terms of use : $\underline{\text { Click here }}$
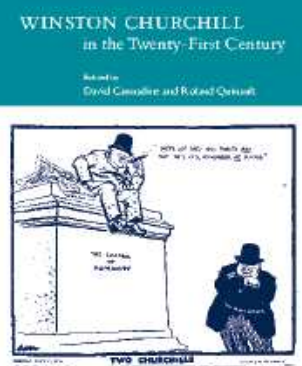

\section{HOUSEWIVES AND SERVANTS IN RURAL ENGLAND, 1440-1650: EVIDENCE OF WOMEN'S WORK FROM PROBATE DOCUMENTS}

Jane Whittle

Transactions of the Royal Historical Society / Volume 15 / December 2005, pp 51 $-74$

DOI: 10.1017/S0080440105000332, Published online: 28 November 2005

Link to this article: http://journals.cambridge.org/ abstract S0080440105000332

How to cite this article:

Jane Whittle (2005). HOUSEWIVES AND SERVANTS IN RURAL ENGLAND, 1440-1650: EVIDENCE OF WOMEN's WORK FROM PROBATE DOCUMENTS. Transactions of the Royal Historical Society , 15, pp 51-74 doi:10.1017/S0080440105000332

Request Permissions : $\underline{\text { Click here }}$ 


\title{
HOUSEWIVES AND SERVANTS IN RURAL ENGLAND, I440-1650: EVIDENGE OF WOMEN'S WORK FROM PROBATE DOCUMENTS*
}

\author{
By Jane Whittle
}

\author{
READ 30 APRIL 2004 AT THE UNIVERSITY OF KENT AT CANTERBURY
}

\begin{abstract}
This essay examines the work patterns of housewives and female servants in rural England between the mid-fifteenth and mid-seventeenth centuries. Despite the fact that such women expended the majority of female work-hours in the rural economy, their activities remain a neglected topic. Here probate documents, wills, inventories and probate accounts are used alongside other types of sources to provide insight into women's work. The three parts of the essay examine the proportion of female servants employed in different households and localities, the types of work that servants and housewives undertook and the scale and level of commercialisation of four common types of women's work.
\end{abstract}

Robert Loder, the seventeenth-century Berkshire farmer who kept a particularly informative set of farm accounts, described the work of his two maid servants as 'the doing of the thinges, that must indeed be donne', and concluded that apart from making malt, they brought him

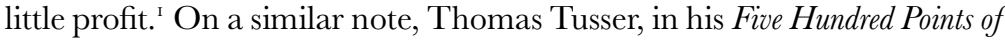
Good Husbandry, wrote, 'Though husbandry semeth, to bring in the gains; yet huswifery labours, seeme equall in paines.' ${ }^{\prime 2}$ Men's work appeared to create the profits, although women worked just as hard. What were 'the things, that must indeed by done' that occupied women in rural households and did their work really bring in little profit? Service and housewifery in rural households was the majority experience of working women in England between the mid-fifteenth and mid-seventeenth centuries. In I60o, an estimated 7o per cent of the English population

\footnotetext{
* This essay was researched and written during an ESRC research fellowship. The collection and analysis of Kent probate inventories was undertaken during an earlier Leverhulme-funded project jointly with Mark Overton, Darron Dean and Andrew Hann, who I would like to thank for their contributions and help. I would also like to thank Ian Mortimer for introducing me to the Kent probate accounts and providing a subject index.

' Robert Loder's Farm Accounts I6ro-I620, ed. G. E. Fussell (Camden Society Third Series 53, I936), $7 \mathrm{I}$.

${ }^{2}$ Thomas Tusser, Five Hundred Points of Good Husbandry United with as Many of Good Huswiferie (I573), sig. S2r.
} 
relied on agriculture for its livelihood, while a further 22 per cent lived in rural areas but carried out other occupations. ${ }^{3}$ According to Kussmaul, servants 'constituted around 6o per cent of the population aged fifteen to twenty-four' in early modern England. ${ }^{4}$ Despite the proportion of the population never marrying reaching a high point in the mid-seventeenth century, marriage, and therefore housewifery, remained the experience of the great majority of adult women. Some rural women worked as day labourers in agriculture, carrying out as much as a third of routine day labouring work on certain farms. ${ }^{5}$ On the whole, however, only women from poorer households worked for daily wages, and only large farmers and gentlemen relied heavily on such workers. The great bulk of womenhours expended on work in rural economy and society was undertaken by housewives and servants.

Yet this majority experience has received little serious historical attention. Although there is a well-known list gleaned from various literary sources of activities commonly allotted to women in rural households, tasks such as spinning, dairying, caring for poultry, cooking, housework, child care and helping in the fields at harvest time, this is only a starting point. The nature of women's work has remained hidden behind generalisations and misconceptions. A lack of documented occupational designations for the great majority of women seems to have led to an assumption that there is little documentary evidence of women's work, and perhaps also that many women had no occupations, neither of which is the case. Also implicit in historians' neglect of the work of housewives and female servants is an assumed insignificance of women's work, often accompanied by its designation as 'domestic', without any detailed consideration of what domestic might mean in an economy in which most production was located in or near the home. Additionally, the idea of what Vickery has described, with irony, as an early modern 'wholesome "family economy" in which men, women and children shared tasks and status', has discouraged historians to looking more carefully at the division of labour between men and women within the household, assuming women's work complemented that of men, and could be subsumed within male occupations. ${ }^{6}$

This essay challenges all of these assumptions, and it does so using probate documents, a source familiar to early modern economic and

${ }^{3}$ E. A. Wrigley, People, Cities and Wealth: The Transformation of Traditional Society (Oxford, I987), I70.

${ }_{4}^{4}$ Ann Kussmaul, Servants in Husbandry in Early Modern England (Cambridge, I98I), 3. Problems with Kussmaul's sources are discussed below.

${ }^{5}$ For example see L. R. Poos, A Rural Society after the Black Death: Essex 1350-I525 (Cambridge, I99I), 2I4 and 2I7; A. Hassell Smith, 'Labourers in Late Sixteenth-Century England: A Case Study from North Norfolk [Part I]', Continuity and Change, 4 (1989), 29.

6 Amanda Vickery, 'Golden Age to Separate Spheres? A Review of the Categories and Chronology of English Women's History', Historical Journal 36 (I99I), 402. 
social historians. Wills record bequests made to servants, while probate accounts record wages owing to them. Wills and accounts also contain information about the age structure of the household. The lists of moveable goods in probate inventories provide evidence of the work carried out. Comparisons between wills, accounts and inventories allow the social structure of particular households, in terms of age, gender and servant employment, to be matched with their economic structure, in terms of production and housework. Probate documents have drawbacks: most notably, they provide only positive rather than negative evidence. If a servant is given a bequest in a will, we know that servant was employed by the household of the testator, but if no servants are given bequests we do not know that no servants were employed. Comparisons with literary descriptions of rural work patterns, household and farm accounts, and other sources remain vital. In terms of sheer numbers and their stretch down the social structure, however, no other type of document from this period can equal the reach of wills and inventories.

The exploration of women's work in this essay is split into three sections. The first examines gendered patterns of servant employment in various types of household. Although it is not possible to deduce the total number of servants employed in this period, the types of households that employed servants, and the types of servants they employed, can be observed. The employment of female servants has been seen as an indicator of the amount of work available for women in rural economies, for instance that pastoral regions employed more female servants than arable areas, because dairying provided more work for women. Thus although rural housewives were found everywhere, the number of female servants provide an indicator of the value of women's work to particular households and economies. This assumes that female servants and housewives carried out the same types of work. In the second section evidence of the types of work carried out by female servants and housewives is examined in detail. The final section argues that key forms of women's work, such as dairying, brewing, baking and spinning, should be understood as by-employments within the household, treated as distinct occupations rather than integral elements of a vaguely defined domestic economy. Although they did not necessarily constitute full-time occupations for women, each has its own history in terms of levels of commercialisation and change over time, effecting women's overall work patterns.

\section{Servants}

Surprisingly little is known about the employment of rural servants in the period between I440 and I650. ${ }^{7}$ In her classic account Kussmaul used

${ }^{7}$ Although see also Jane Whittle, 'Servants in Rural England c. I450-I650: Hired Work as a Means of Accumulating Wealth and Skills before Marriage', in The Marital Economy of Scandinavia and Britain 1400-1900, ed. Maria Agren and Amy Erickson (2005), 89-107. 
Ioo parish listings, dating from I574 to I82I, to examine patterns of servant employment. She found that 'the overall ratio of male to female servants is I07:IO0' although the ratios in farmers' and craftsmen's households were more biased towards men, at I2г:I00 and I7r:I00. ${ }^{8}$ However, Kussmaul's data-set is heavily skewed to the period after I650: of the Ioo listings, only five date from before 1650 , of which three relate to rural communities, and only one of these, the I599 listing from Ealing, records the occupation or status of servant employers. ${ }^{9}$ Unlike Kussmaul's analysis, Wall's study of the Marriage Duty Act data of $c$. I 700 records regional differences in the sex ratio of servants. ${ }^{10}$ Goldberg, comparing this with late fourteenthcentury evidence from the Poll Tax returns, suggest a threefold division of servant employment patterns, 'which saw service to be more feminised in urban and pastoral communities than rural, arable communities'. In towns and cities female servants typically outnumbered male servants, in rural pastoral regions there were equal numbers, while in arable areas males outnumbered females in service by as much as two to one. ${ }^{\text {II }}$

In the absence of useable tax returns or parish listings, other than that for Ealing, Table I takes bequests to servants in wills as an indication of servant employment patterns. These wills were made by rural householders, yet they record a dominance of female servants: male servants are outnumbered by female servants at a ratio of 78: Ioo. Only one collection of wills, that from Lincolnshire, showed a male predominance. There are hints of regional contrasts. Two small collections, from Swaledale in Yorkshire and Uffculme in Devon, both areas where pastoral farming and textile production were combined, show the highest proportion of female servants, with three or more women to each man employed. Other regions strongly represented here, such as Suffolk and Halifax, as well as north-east Norfolk, also combined dairying with cloth production, although in Suffolk and Norfolk arable farming was carried out as well. Only the small sample from King's Langley, Hertfordshire, comes from an arable region with large farms. ${ }^{12}$ The selection of wills

\footnotetext{
${ }^{8}$ Kussmaul, Servants in Husbandry, 4 .

9 The Ioo are listed in P. Laslett, 'Mean Household Size in England since the Sixteenth Century', in Household and Family in Past Time, ed. P. Laslett and R. Wall (Cambridge, 1972), I30-I. Those giving occupational details are listed in Kussmaul, Servants in Husbandry, I2-I3.

${ }^{10}$ Richard Wall, 'Regional and Temporal Variations in English Household Structure from i65o', in Regional Demographic Development, ed. J. Hobcraft and P. Rees (I977), I0o-io. Wall compares parishes from East Kent, East Wiltshire, Southampton, Shrewsbury and London.

${ }^{11}$ P. J. P. Goldberg, Women, Work and Life Cycle in a Medieval Economy: Women in York and Yorkshire c. ${ }^{1300-1520}$ (Oxford, 1992), I6o.

${ }^{12}$ For agricultural regions see Joan Thirsk, England's Agricultural Regions and Agrarian History, I5OO-I750 (Basingstoke, I987), particularly 28. For north-east Norfolk see Jane Whittle, The Development of Agrarian Capitalism: Land and Labour in Norfolk I44O-I580 (Oxford, 2000), 259.
} 
Table I Bequests to servants in wills, I439-I650

\begin{tabular}{|c|c|c|c|c|}
\hline & $\begin{array}{l}\text { Number } \\
\text { of wills or } \\
\text { accounts }\end{array}$ & $\begin{array}{c}\text { Percentage } \\
\text { mentioning } \\
\text { servants }\end{array}$ & $\begin{array}{c}\text { Number of } \\
\text { servants } \\
\text { with gender } \\
\text { specified }\end{array}$ & $\begin{array}{c}\text { Percentage } \\
\text { of servants } \\
\text { female }\end{array}$ \\
\hline I. West Suffolk wills I439-6 I & 887 & 7.6 & 87 & 55 \\
\hline $\begin{array}{l}\text { 2. North-east Norfolk } \\
\text { wills I } 44^{-}-\mathrm{I} 579\end{array}$ & 234 & $\mathrm{I} 3.2$ & 60 & 57 \\
\hline $\begin{array}{l}\text { 3. Wills from Halifax, } \\
\text { Yorks. } 5^{500-59}\end{array}$ & 534 & 8.8 & 6I & 6I \\
\hline 4. Lincolnshire wills $\mathrm{I}_{5} \mathrm{O}^{-}-3^{2}$ & $\mathrm{I}, \mathrm{O} 24$ & $\mathrm{I} 2.0$ & 182 & 45 \\
\hline $\begin{array}{l}\text { 5. Wills from King's } \\
\text { Langley, Herts. I } 498-1650\end{array}$ & Iog & 8.3 & 8 & $5^{0}$ \\
\hline $\begin{array}{l}\text { 6. Wills from Swaledale, } \\
\text { Yorks. I522-1600 }\end{array}$ & 205 & $7 \cdot 3$ & I9 & 80 \\
\hline $\begin{array}{l}\text { 7. Wills from Uffculme, } \\
\text { Devon, } 1545^{-1} 649\end{array}$ & I33 & I0.5 & I6 & 75 \\
\hline 8. East Suffolk wills I62o-6 & I, 136 & 6.5 & Io6 & 62 \\
\hline 9. West Suffolk wills I63o-5 & 894 & $5 \cdot \mathrm{I}$ & 62 & 65 \\
\hline Total & 5,156 & 8.4 & $60 \mathrm{I}$ & $5^{6}$ \\
\hline Iо. Essex gentry wills I558-i6o3 & $27 \mathrm{I}$ & 55 & - & - \\
\hline II. Kent probate accounts i6 I I-25 & 734 & I5.0 & I89 & 47 \\
\hline
\end{tabular}

Sources: I. Wills of the Archdeaconry of Sudbury, I439-I474, I, ed. Peter Northeast (Suffolk Records Society 44, 200I). 2. Norfolk Record Office, Norwich: all surviving wills for the parishes of Brampton, Corpusty, Hevingham, Marsham, Saxthorpe and Scottow, I440-1580, from the Norwich Consistory Court, Norwich Archdeaconry Court, and Norfolk Archdeaconry Court. 3 . Halifax Wills: Part I, 1389-I544, ed. J. W. Glay and E. W. Crossley (privately printed, undated), and Halifax Wills: Part 2, 1545-59, ed. E. W. Crossley (privately printed, undated). 4. Lincoln Wills, I, ed. C. W. Foster (Lincoln Record Society 5, I9I2); Lincoln Wills, II, ed. C. W. Foster (Lincoln Record Society I0, I9I4); and Lincoln Wills, III, ed. C. W. Foster (Lincoln Record Society 24, I927). 5. Life and Death in Kings Langley: Wills and Inventories 1498I659, ed. Lionel Munby (Kings Langley, I98I). 6. Swaledale Wills and Inventories I522-I6oo, ed. Elizabeth K. Berry (Yorkshire Archaeological Society Record Series I52, I995 and 1996). 7. Uffculme Wills and Inventories: Sixteenth to Eighteenth Centuries, ed. Peter Wyatt (Devon and Cornwall Record Society New Series 40, I997). 8. Wills of the Archdeaconry of Suffolk I620-I624, ed. Marion E. Allen (Suffolk Records Society 3I, I988/9), and Wills of the Archdeaconry of Suffolk I625-I626, ed. Marion E. Allen (Suffolk Records Society 37, I995). 9. Wills of the Archdeaconry of Sudbury I630-I635, ed. Nesta Evans (Suffolk Records Society 29, I987). Io. Elizabethan Life: Wills of Essex Gentry and Merchants Proved at the Prerogative Court of Canterbury, ed. F. G. Emmison (Chelmsford, I978). II. Centre for Kentish Studies, Maidstone [hereafter CKS], Archdeaconry Court of Canterbury account papers, $\mathrm{PRC}_{2} / \mathrm{I} 6, \mathrm{PRC}_{2} / \mathrm{I}_{8}, \mathrm{PRC}_{2} / 23$ and $\mathrm{PRC}_{2} / 24$. 
in Table I is biased towards eastern England, in later centuries a region dominated by arable farming. Yet before i65o England's rural economy was less specialised than it became by the eighteenth century. ${ }^{13}$ The predominance of mixed farming, as well as smaller farm sizes, seems to have favoured the employment of female servants.

It is possible that there is a bias towards female servants in bequests, either because women earned less and were seen as more deserving recipients of gifts, or because female servants developed closer relationships with employing families, but this is difficult to prove. Kent probate accounts, which record wages owing to servants at time of death, rather than bequests, record larger numbers of servants, and contain a lower proportion of women than most of the will collections. Without an identical sample of wills, however, we cannot separate the effect of differences in documentation from regional variations. Accounts, like wills, under-record servants, as not all servants had wages owing that had to be paid by an administrator. Evidence from bequests in wills is problematic in other ways. Obviously, will-makers were under no obligation to leave bequests to servants. Henry Best, whose famous Farming and Memorandum Books records a household of eight servants, left no bequests to servants in his will of ${ }^{1} 645 .{ }^{14}$ Employment of servants was almost universal amongst the gentry, yet only 55 per cent of wills of Essex gentry record such bequests. Unfortunately, it was impossible to look at the gender balance of gentry servants, as the majority of these wills had general clauses, such as bequests 'to all my manservants' or 'maidservants' or 'the servants resident in my household'. Nor can it be certain that ordinary will-makers necessarily described servants in a way that allows them to be distinguished from other beneficiaries. For these reasons, the incidence of bequests to servants in wills is only a minimum level of servant employment, not the true level. However, when servants are mentioned, it does allow servant employment to be observed in a wide spectrum of household types.

The evidence from wills is set in context by comparisons with other types of document. Farm and household accounts record wage payments to servants. Such accounts are both relatively rare, and atypical of rural households. With farms of between 250 and 700 acres, in a period when the majority of farms were under 50 acres in size, ${ }^{15}$ the households of the wealthy yeomanry and gentry represent a more smaller, wealthier, section of society than wills. Wealthy households employed large numbers

\footnotetext{
${ }^{13}$ Ann Kussmaul, A General View of the Rural Economy of England, I538-I84o (Cambridge, I990), 3 .

${ }_{14}$ The Farming and Memorandum Books of Henry Best of Elmswell ${ }_{1} 642$, ed. Donald Woodward (Oxford, I984), 247-9.

${ }^{15}$ See Whittle, Agrarian Capitalism, 190; Robert Allen, Enclosure and the Yeoman: The Agrarian Development of the South Midlands 1450-I850 (Oxford, 1992), 73.
} 
of servants: all the households in Table 2 employed at least four or five servants per year, while four had more than ten. On average, these ten households employed eight servants per year: two women and six men; only one in four servants was female. ${ }^{16}$

The Ealing 'census' of I599 records the occupation or status of heads of household as well as listing household members including servants. Although Ealing is now part of west London, at the end of the sixteenth century it was a rural community dominated by farming, some eight miles from the City. Nonetheless, like many parishes just outside London, it had a large number of wealthy households, with nine belonging to gentlemen, merchants and wealthy professionals, and this affected its profile of servant employment. Elsewhere in England many villages had no gentry households at all. ${ }^{17}$ Correspondingly there was an unusually high proportion of servants in Ealing, making up 24 per cent of its population. Of these servants, 4 I per cent were female, giving a gender ratio of I4I:Ioo. ${ }^{18}$ However, servants, male and female, were not evenly spread between households. All wealthy households and households of yeomen employed servants, while only 20 per cent of other households did. In yeomen's households, 25 per cent servants were female, compared to 39 per cent in the households of gentlemen and other wealthy farmers, while in the households of ordinary farmers, 57 per cent of servants were women. Taken together, evidence from wills, household accounts and the Ealing census demonstrate that patterns of servant employment were influenced by a household's wealth as well as its production regime. Wills representing ordinary rural households of moderate wealth indicate that such households more often employed women than men, as did husbandmen in Ealing. Household accounts show a strong bias towards male servants, as did Ealing's yeomen. For the gentry the picture is more mixed, and we can speculate that patterns on servant employment varied according to the balance between farming and running a large household.

Further confirmation of this pattern is provided by probate accounts from Kent, which allow patterns of servant employment to be compared to inventoried wealth. ${ }^{19}$ The employment of a lone female servant

${ }^{16}$ These numbers are approximate due to variations in employment patterns from year to year.

${ }^{17}$ In the ${ }_{1520}$ s, thirty-nine parishes studied in north-east Norfolk, with an estimated population of 4,350, contained only twenty-three resident gentry households. Wealthy nongentry concentrated in market towns. Whittle, Agrarian Capitalism, 203 and $210-11$.

${ }^{18}$ A 1562 communicant list from Romford, on the other side of London, indicates a similar servant gender ratio of I38:Ioo: M. K. McIntosh, A Community Transformed: The Manor and Liberty of Havering, 1500-1620 (Cambridge, I99I), 37.

${ }^{19}$ Inventoried wealth was the total value of moveable goods owned by the deceased, including debts owing to that person. The final balance of the probate account, after funeral expenses, debts owed and various other payments had been made, was considered a less accurate measure of previous wealth. See also Mark Overton, Jane Whittle, Darron Dean and Andrew Hann, Production and Consumption in English Households, I6oo-I750 (Abingdon, 2004), 138 . 
Table 2 Servants recorded in farm and household accounts

\begin{tabular}{|c|c|c|c|}
\hline Owner, location, date & $\begin{array}{l}\text { Size of farm and type } \\
\text { of agriculture }\end{array}$ & $\begin{array}{c}\text { Female servants (number } \\
\text { and any work details) }\end{array}$ & $\begin{array}{l}\text { Male servants (number } \\
\text { and any work details) }\end{array}$ \\
\hline $\begin{array}{l}\text { I. John Capell: Porter's } \\
\text { Hall, Stebbing, Essex: } \\
\text { I } 483-4 \text {. }\end{array}$ & $\begin{array}{l}300 \text { acres of crops }+ \\
\text { several dozen cattle } \\
\text { and other livestock. }\end{array}$ & I, no description. & Io, no description. \\
\hline $\begin{array}{l}\text { 2. Humphrey Newton: } \\
\text { Newton, Cheshire: } \\
\text { I498-I520. }\end{array}$ & $\begin{array}{l}\text { Approx. Ioo acres of } \\
\text { arable and I5o of } \\
\text { pasture. }\end{array}$ & $\begin{array}{l}\text { 2-3, brewed, made } \\
\text { cheese, spun flax } \\
\text { and hemp. }\end{array}$ & ${ }^{2-} 3$, no description. \\
\hline $\begin{array}{l}\text { 3. Peter Temple: Burton } \\
\text { Dassett, Warwickshire: } \\
\text { I543-8. }\end{array}$ & $\begin{array}{l}665 \text { acres of enclosed } \\
\text { pasture, fattening } \\
\text { cattle, sheep and a } \\
\text { few milk cows. }\end{array}$ & $\begin{array}{l}\mathrm{O}-3 \text {, no description } \\
\text { (records incomplete). }\end{array}$ & $\begin{array}{l}\text { 2-6, also at least } \\
\text { one shepherd } \\
\text { (records incomplete). }\end{array}$ \\
\hline $\begin{array}{l}\text { 4. Roberts family: } \\
\text { Boarzell, Sussex: } \\
\text { I568-70. }\end{array}$ & $\begin{array}{l}300 \text { acres of pasture, } \\
\text { arable and woods. } \\
\text { Beef cattle and sheep, } \\
\text { some cows. }\end{array}$ & $2-3$, no description. & $\begin{array}{l}7-8 \text { male servants } \\
\text { of whom } 2 \text { were } \\
\text { boys. }\end{array}$ \\
\hline $\begin{array}{l}\text { 5. Nathaniel Bacon: } \\
\text { Stiffkey, Norfolk: } \\
\text { I587-97. }\end{array}$ & $\begin{array}{l}\text { Approx. } 600 \text { acres; } \\
\text { mixed, mainly arable } \\
\text { farming including } \\
\text { saffron and hops. }\end{array}$ & $2-3$, all dairy maids. & $\begin{array}{l}\text { 8-Io, including a } \\
\text { bailiff, sub-bailiff } \\
\text { and stockman. }\end{array}$ \\
\hline
\end{tabular}


6. Robert Loder: Harwell, Berkshire: I6IO-20.

7. Henry Best: Elmswell, East Riding Yorks.: i6I7-44.

8. Nicholas Toke: Godinton estate, near Ashford, Kent: I626-8.

9. Reynell family: Forde, south Devon: I627-33.

Io. Willoughby family: Leyhill, east Devon: I644-6.
Approx. I50 acres of arable and Ioo acres of pasture.

$360(+)$ acres of arable and Ioo acres of pasture. I4 milk cows.

'An estate of considerable size.'

No information.

No information, but in I644 sold butter and $800 \mathrm{lb}$ of cheese.
2 usually, did malting.

I-3, washing, milking, brewing and baking.

I, no description.

5 , including a chamber maid and a dairymaid.

4, including one dairymaid.
2 usually, as well as a carter and a shepherd.

$4^{-6}$, foreman, 3 other men, 2 boys, details of work given.

8, no description.

8 , including a cook, coachman, buttery boy and ploughman.

6 male servants.

Sources: I. L. R. Poos, A Rural Society after the Black Death: Essex I350-I525 (Cambridge, I991), 212-18. 2. Deborah Youngs, 'Servants and Labourers on a Late Medieval Demesne: The Case of Newton, Cheshire, I498-I520', Agricultural History Review, 47 (I999), I456o. 3. Warwickshire Grazier and London Skinner I532-I555. The Account Book of Peter Temple and Thomas Heritage, ed. N. W. Alcock (Oxford, I98I). 4. Accounts of the Roberts Family of Boarzell, Sussex, c. I568-I582, ed. Robert Tittler (Sussex Record Society 7I, I977-9). 5. A. Hassell Smith, 'Labourers in Late Sixteenth-Century England: A Case Study from North Norfolk [Part I]', Continuity and Change, 4 (I989), I I-52. 6. Robert Loder's Farm Accounts I6Io-I620, ed. G. E. Fussell (Camden Society Third Series 53, I936). 7. The Farming and Memorandum Books of Henry Best of Elmswell I642, ed. Donald Woodward (Oxford, I984). 8. The Account Book of a Kentish Estate I6I6-I704, ed. Eleanor G. Lodge (Oxford, I927). 9 and io. Devon Household Accounts, I627-59, Part I, ed. Todd Gray (Devon and Cornwall Record Society New Series 38, 1995). 
Table 3 Servant employment in the Ealing 'census' of I599

\begin{tabular}{|c|c|c|c|c|}
\hline & $\begin{array}{l}\text { Number of } \\
\text { households }\end{array}$ & $\begin{array}{l}\text { Percentage of } \\
\text { households } \\
\text { with servants }\end{array}$ & $\begin{array}{c}\text { Number of } \\
\text { servants }\end{array}$ & $\begin{array}{c}\text { Percentage } \\
\text { of servants } \\
\text { female }\end{array}$ \\
\hline All & 85 & $34 \cdot \mathrm{I}$ & IO4 & $4 \mathrm{I} \cdot 3$ \\
\hline Farming & $5^{2}$ & 40.4 & 87 & $3^{6.7}$ \\
\hline Non-farming & 33 & 24.2 & I7 & 64.7 \\
\hline Wealthy & 9 & IOO.O & $5^{2}$ & 44.2 \\
\hline Yeomen & 6 & IOO.O & 32 & 25.0 \\
\hline Others & 70 & 20.0 & 20 & 60.0 \\
\hline Wealthy farmers & 6 & IOO.O & $4 \mathrm{I}$ & 39.0 \\
\hline Yeomen & 6 & IOO.O & 32 & $25 \cdot 0$ \\
\hline Husbandmen & 40 & 22.5 & I4 & $57 \cdot \mathrm{I}$ \\
\hline
\end{tabular}

Source: K. J. Allison, An Elizabethan 'Census' of Ealing (Ealing, I962).

Table ${ }_{4}$ Kent probate accounts mentioning servants, ${ }_{1} 6 I I-25$

\begin{tabular}{|c|c|c|c|c|c|c|c|}
\hline & \multicolumn{2}{|c|}{$\begin{array}{c}\text { Households } \\
\text { with servants }\end{array}$} & \multicolumn{2}{|c|}{$\begin{array}{l}\text { Female } \\
\text { servants }\end{array}$} & \multicolumn{2}{|c|}{$\begin{array}{c}\text { Male } \\
\text { servants }\end{array}$} & \multirow{2}{*}{$\begin{array}{c}\text { Average } \\
\text { inventoried } \\
\text { wealth of } \\
\text { household }\end{array}$} \\
\hline & (No.) & $(\%)$ & (No.) & $(\%)$ & (No.) & $(\%)$ & \\
\hline $\begin{array}{c}\text { One female } \\
\text { servant }\end{array}$ & $3^{6}$ & 33 & $3^{6}$ & $4 \mathrm{I}$ & - & - & £68 \\
\hline $\begin{array}{r}\text { One male } \\
\text { servant }\end{array}$ & I9 & I7 & - & - & I9 & I9 & $E^{\mathrm{I}} 4 \mathrm{I}$ \\
\hline Two servants & I6 & I5 & I5 & I7 & I5 & I5 & fil3 \\
\hline $\begin{array}{c}\text { Three or more } \\
\text { servants }\end{array}$ & 28 & 25 & 37 & 42 & 67 & 66 & EI I99 \\
\hline $\begin{array}{l}\text { Servants, number } \\
\text { unspecified }\end{array}$ & I I & IO & - & - & - & - & $\AA^{262}$ \\
\hline Total & IIO & IOO & 88 & IOO & IOI & IOO & (average $\mathrm{f}_{\mathrm{I}} \mathrm{O}$ ) \\
\hline
\end{tabular}

Source: CKS, Archdeaconry Court of Canterbury account papers, $\mathrm{PRC}_{2}$ / 16 , $\mathrm{PRC}_{2} / \mathrm{I}, \mathrm{PRC}_{2} / 23$ and $\mathrm{PRC}_{2} / 24$.

was the most common pattern, found in 33 per cent of accounts mentioning servants. These households had an average inventoried wealth of $\mathcal{E}^{68}$, less than half of that of households who employed a 
lone male servant, with an average wealth of $f_{\mathrm{I}} \mathrm{I}$, while, as we would expect, households with three or more servants, and with unspecified numbers of servants, were wealthier still. Again, these findings also suggest that female servants were more likely to be employed in poorer households than men, and were more often employed on their own, as the lone servant.

All the documents examined here have weaknesses, but considered together they start to build a representative picture of servant employment in rural England in the period I440-I650. They demonstrate that servant employment was widespread both geographically and socially. Nonetheless, the levels of wealth and occupational structures created by local economies affected both the number of households employing servants and the number and type of servants, male or female, that households employed. The households of gentry and wealthy yeomen farmers always contained servants in this period: normally four or more such employees. These almost always included women as well as men, but more men than women were employed. Lower down the social scale servant employment remained quite common, but typically only one, or at most two, servants were employed and many households did not have a servant. When a lone servant was employed, such a person was more often a woman than a man. It seems likely that in some localities, such as Uffculme in Devon and Swaledale in Yorkshire, where small farms predominated, and dairying and spinning were important elements of the local economy, female servants outnumbered their male counterparts. The gender of servants employed was determined not only by the productive activities of the household, and therefore of a region, but also within regions and localities, by the wealth of the particular household concerned.

\section{Work}

Just as male servants in rural households gained a training in husbandry, the work of a male farmer, so, in theory, female servants gained a training in the various arts of housewifery, the work of a housewife. ${ }^{20}$ Exactly what types of work female servants and housewives really did in particular households, however, needs investigation. ${ }^{21}$ Wage assessments set the legal maximum rates of pay that could be given to any hired worker, including servants. Thirty-six wage assessments dating from between I444 and I65I were examined for job descriptions of female servants. Most gave no information about the types of work female servants might

\footnotetext{
${ }^{20}$ Kussmaul, Servants in Husbandry, 34 .

${ }^{21}$ Some of the material in the following section is discussed in more detail in Whittle, 'Servants in Rural England'.
} 
do, differentiating wage rates in terms of age or general descriptions such as 'best woman servant' and 'common servant'. However, eight did provide details, listing the skills more experienced female servants might be expected to have: cooking, baking, malting, brewing, dairying, overseeing other servants and being 'able to take charge of a household'.$^{22}$ Specialist jobs mentioned for female servants were dairy maid, malt maker, wash maid and chamber maid, although out of the assessments studied, the last two specialisms were only listed in Essex in I65I. Dairying, mentioned specifically in six assessments, was the most common form of specialist female farm service listed.

Henry Best's Farming and Memorandum Books, describing the running of his large farm in east Yorkshire in the first half of the seventeenth century, notes that his two female servants were responsible for milking fourteen cows. When he hired a maid servant, Best asked if she had 'beene used to washinge, milkinge, brewinge, and bakinge' and assumed that every maid knew how to clean and tidy a house. As with his male servants, he expected his maids to be strong and able to do hard physical work. ${ }^{23}$ Another well-known source from the early seventeenth century, already quoted, is Robert Loder's farm accounts. Loder had a large arable farm in Berkshire, and like Best, he employed two female servants each year. He regarded malt-making to be their most profitable task. It was certainly an important aspect of Loder's farm economy, as he sold between $\AA_{17} 6$ and $£_{12} 22$ worth of malted barley each year. However, Loder's accounts also record his maids doing other types of work: each year they made hay and helped with the grain harvest, one year the maids picked and sold his cherries, in other years they only sold them and other women were hired to pick them. In I6Ig Loder calculated that one of his maids spent twenty-one days selling cherries, travelling to market with a horse each day. ${ }^{24} \mathrm{~A}$ maid was also responsible for selling apples. In I6I8, when Loder expanded his dairy, the maids helped with the milking, supplementing workers employed by the day. ${ }^{25}$

Additionally, Loder's maids also carried out those tasks he described as 'the doing of the thinges, that must indeed be donne'. What these were requires speculation. Loder records that his household, which comprised

\footnotetext{
${ }^{22}$ These were assessments from Northamptonshire 1560: B. H. Putnam, 'Northamptonshire Wage Assessments of I560 and I667', Economic History Review, I (I927), I3I-2; Worcester 156o: D. Woodward, 'The Background to the Statute of Artificers: The Genesis of Labour Policy I558-63', Economic History Revierw, 33 (1980), 42-3; Rutland I563, and Colchester, Essex, I583: Tudor Royal Proclamations, II, ed. P. L. Hughes and J. F. Larkin (New Haven, I969), 215-18 and 499-50r; East Riding of Yorkshire I593, Oakham, Rutland I6ro and Essex I651: F. M. Eden, The State of the Poor (I966), xc-xcii, xcv-xcvii and xcviii-ci; and Suffolk i63o: W. A. J. Archbold, 'An Assessment of Wages for I63o', English Historical Review, I2 (1897), 307-II.

${ }^{23}$ Henry Best, ed. Woodward, I38-42.

${ }^{24}$ Robert Loder, ed. Fussell, I69.

${ }^{25}$ Ibid., I54.
} 
himself, his wife, five servants and his young children, was fed primarily from his farm's own produce. Not only was cheese made on the farm, but wheat was consumed, presumably as bread; malt and hops were consumed, presumably in beer; and hogs were fattened. ${ }^{26}$ Someone made the cheese, baked the bread, brewed the beer, fed the pigs and preserved and prepared their meat. It is likely that this was done by Loder's wife and the two maid servants, although this is never stated. It is worth noting that the majority of adults in the household were paid employees, and Loder notes that day labourers also consumed as much food and drink as one more resident adult, so the bulk of this food processing work was undertaken to feed workers rather than to provide for a nuclear family.

Literary evidence has often been used to provide basic descriptions of rural women's work. Four well-known literary works from this period which provide such descriptions are the anonymous late fifteenth-century Ballad of the Tyrannical Husband; ${ }^{27}$ Fitzherbert's early sixteenth-century Boke of Husbandry ${ }^{28}$ Thomas Tusser's Five Hundred Points of Husbandry from later that century; ${ }^{29}$ and Gervase Markham's The English Housewife published in I6I5. ${ }^{30}$ The Ballad of the Tyrannical Husband takes the form of an argument between husband and wife over who does the most work. While the husband's work is satirised as consisting solely of ploughing, the wife's list of tasks is long: she milked cows, made butter and cheese, cared for poultry, baked, brewed, processed flax, spun wool and made cloth, as well as preparing meals and keeping the house tidy. Her burden of farm and craft work came on top of child care: she complains that her 'sleep is but small' as she lies 'all night awake with our child' but still tidies the house and milks the cows each morning before her husband gets up. The image of women's hard work and many tasks was not restricted to the genre of satirical popular songs. It is a point also made in Fitzherbert's and Tusser's farming advice manuals. Fitzherbert offered advice on time management to the housewife rather than the husbandman, recognising that she was frequently faced with multiple tasks and had to make difficult decisions about which was most urgent, and most likely to profit the household. ${ }^{31}$ Tusser noted that while the husbandman had seasonal respites when less work needed to be done, the housewife's tasks 'have never an end', combining a daily cycle with seasonal work..$^{22}$

\footnotetext{
${ }^{26}$ For example, ibid., 44-5.

${ }^{27}$ Women in England c. 1275-1525: Documentary Sources, ed. P. J. P. Goldberg (Manchester, I995), I69-70.

${ }_{28}^{28}$ John Fitzherbert, The Boke of Husbandry (I533).

${ }_{29}$ Tusser, Five Hundred Points.

${ }^{30}$ Gervase Markham, The English Housewife, ed. Michael R. Best (Montreal, 1994).

${ }^{31}$ Fitzherbert, Boke of Husbandry, sig. $\mathrm{K}_{4} \mathrm{r}-\mathrm{v}$.

${ }^{32}$ Tusser, Five Hundred Points, sig. S2r. Tusser's advice to husbandmen follows a seasonal routine, but includes tasks carried out by women; his advice to housewives follows a daily routine.
} 
Both Fitzherbert and Tusser admit a degree of ignorance about women's work. The parts of their books which refer to women's work are not so much advice as lists of tasks a husband could expect his wife to undertake, lists which are much the same as that in the Ballad. Markham's The English Housewife was a new departure in offering detailed advice about a range of women's tasks. Some of these seem more appropriate to gentlewomen than the average housewife. Chapters describe medicinal remedies, elaborate cookery, the distillation of vinegars and perfumes and keeping wine, as well as the more common 'offices' of housewifery: processing wool, hemp and flax, dairying, malting, brewing and baking and, rather strangely, 'the excellency of oats'. Children are not mentioned, nor is laundry or other forms of cleaning, and poultry only appear as the recipients of oatmeal. Markham is also silent about the generation of income. Fitzherbert suggests a wife should keep her own accounts, but should report her financial affairs to her husband, just as he should report to her. She should generate her own income by going 'to the market, to sell butter, chese, mylke, egges, chekyns, capons, hennes, pygges, gese, \& al maner of cornes' ${ }^{33}$ That the housewife should make money by selling products as well as saving money by producing things at home is a point repeated by both the Ballad and Tusser.

Literary evidence provides a list of tasks women might be expected to do in a rural household, but it should not be mistaken for representative evidence of what rural women actually did. It is both incomplete, and too comprehensive, as a picture of what real women did. On the one hand some obvious tasks are omitted or only briefly mentioned, such as child care, fetching water and fuel, and laundry. On the other, it would be a mistake to imagine that all rural women carried out all these tasks. There were differences according to types of farming and the wealth of the household, and, presumably, differences in particular women's aptitude and enthusiasm. There was also change over time, particularly in the opportunities to earn money.

The nature of women's work in particular households is described in probate documents. Less wealthy rural households commonly employed one female servant: what work did such women do? Cross-referencing wills or probate accounts which mentioned servants with probate inventories which list the moveable goods owned by a household gives an indication of the work activities carried out. Wills and accounts also contain information about household structure, for instance, whether the family contained young children or the elderly who required extra care. Given that female servants were so often employed in relatively poor households, with a sparse domestic environment, it seems unlikely they were primarily concerned with cooking and cleaning. Ordinary rural

${ }^{33}$ Fitzherbert, Boke of Husbandry, sig. $\mathrm{K}_{4} \mathrm{v}^{-} 5 \mathrm{r}$. 
households would not have been able to afford such a luxury. Roger Alderson of Grinton in Swaledale, north Yorkshire, left a milk cow to his servant, Katherine Alderson, when he made his will in ${ }^{5} 54{ }^{I}{ }^{34}$ It is possible Katherine was a relation; however, Roger described her simply as 'my servant'. He also left bequests to his wife and children, so he was not without close family. Architectural evidence and sixteenthcentury probate inventories indicate a very basic living environment in Swaledale's upland farms. ${ }^{35}$ Most dwellings consisted of a single living room, and inventories demonstrate that the majority of moveable wealth consisted of livestock rather than household goods. It seems likely that Katherine helped care for cows and sheep, milking and making cheese and butter, as well as spinning wool: the main elements of the local economy. She may also have helped care for the family's children. Sarah Thompson, a Kent widow, was wealthier than Roger Alderson, but, with seven children under the age of eleven, must have needed help with child care. She employed one female servant. Nonetheless, Sarah's inventory also records 'cattle, horses, kine, sheep, hogs and husbandry instruments' worth $£ 80$, indicating that there was farming work to be done..$^{6}$

Records of inheriting children's ages in probate accounts correlated with servant employment show that female servants were more likely to be employed if there were children under the age of six in the household, although the sample is very small. ${ }^{37}$ Out of sixty-five households leaving accounts mentioning servants, seventeen could be identified as containing young children. Fourteen, or 82 per cent, of these employed female servants, compared to 65 per cent in the whole sample as a whole..$^{8}$ It is often assumed that the location of women's work in or near the home in early modern England made child care easily compatible with other forms of work, but was this really the case? Surely there were difficulties in combining work in the fields, dairying (which required careful timing and a high degree of cleanliness), brewing or laundry (which required large quantities of heated water) with the care of small children. Cases of accidental death from sixteenth-century Sussex coroners' inquests suggest that there were sometimes problems. For instance, Alice Tuckenes, a

${ }^{34}$ Swaledale Wills and Inventories $1522-1600$, ed. Elizabeth K. Berry (Yorkshire Archaeological Society Record Series I52, I995 and I996), 56.

35 Ibid., 3 .

${ }^{36}$ CKS, Archdeaconry Court of Canterbury: Sarah Thompson of Wye: Inventory i I.9.I 93 (I642); Account PRGi/7/68 (I645).

${ }^{37}$ The sample used here is the sixty-five Kent probate accounts that could be crossreferenced with probate inventories, described in more detail below.

${ }^{3^{8}}$ The effect disappears if older children are included: 64 per cent of households with children under fifteen had female servants, compared to 62 per cent of the sample more generally. 
servant of John Neve, left his daughter Susan sitting in a small chair in his house while she went out to milk the cows. While she was out Susan fell into the fire and died soon afterwards. Mary Water, aged one and a half, was in the kitchen of her father's house in the care of two servants. One went outside to empty a tub of hot water, while the other went to settle a swarm of bees; while they were gone Mary fell into a tub of water and drowned. ${ }^{39}$

Another context of female servant employment was in the households of single or widowed men, carrying out the work tasks normally allotted to a wife. William Read of Ashell in Uffculme, Devon, was widowed, with grown up children and grandchildren, when he made his will in ${ }^{5} 576$. He nevertheless had a small working farm with three cows, three sheep, three pigs and growing corn, as well as cheese, butter, bacon, lard, corn and hay stored in the house and barn. William left his servant Katherine Landman a small bequest of two shillings. Unless other servants were employed, but not remembered in the will, Katherine must have worked hard, cooking, cleaning, caring for livestock and processing farm products into preserved foodstuffs. ${ }^{4^{\circ}}$ Unmarried men of whatever age were likely to need the assistance of female servants to run a household. John Buntyng of Tostock in mid-Suffolk, who made his will in I440, left bequests to two female servants. One received 'a bullock, a brass pot holding a gallon and 8 bushels of barley', while the other received 'four bushels of barley'; the main beneficiary of his will, however, was his niece, who received '20s. and a cow two years old'. The range of the bequests suggests a farm producing barley and livestock, as well as malting, brewing and dairying on a small scale. ${ }^{4}$

These examples can be supplemented by a more systematic analysis of probate documents. Sixty-five Kent probate accounts from the first half of the seventeenth century which recorded servants' wages were matched with probate inventories from the same households, to compare servant employment patterns with material evidence of four common forms of women's work: dairying, spinning, baking and brewing..$^{2}$ Comparisons have to be restricted to contrasting households with female servants to those with only male servants, as households without servants at all cannot be identified, thus the numbers are quite small; however, the results were unexpected. We might predict that households with evidence of the classic women's occupations - milk cows for dairying, spinning wheels,

${ }^{39}$ Sussex Coroners' Inquests I558-I603, ed. R. F. Hunnisett (Kew, I996), I2 and 24.

${ }^{40}$ Uffculme Wills and Inventories: Sixteenth to Eighteenth Centuries, ed. Peter Wyatt (Devon and Cornwall Record Society New Series 40, 1997), 4. Reade's inventoried wealth came to a

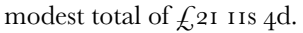

${ }^{41}$ Wills of the Archdeaconry of Sudbury, I439-I474, I, ed. Peter Northeast (Suffolk Records Society $44,200 \mathrm{I}), 53$.

$4^{42}$ CKS, Archdeaconry Court of Canterbury probate inventories and accounts. 
Table 5 Evidence of women's work in Kent probate inventories, I6oo-49

\begin{tabular}{lccccr}
\hline \hline & $\begin{array}{c}\text { Spinning } \\
(\%)\end{array}$ & $\begin{array}{c}\text { Dairying } \\
(\%)\end{array}$ & $\begin{array}{c}\text { Brewing } \\
(\%)\end{array}$ & $\begin{array}{c}\text { Baking } \\
(\%)\end{array}$ & $\begin{array}{r}\text { Number of } \\
\text { inventories }\end{array}$ \\
\hline All & 47 & 55 & 39 & 34 & I, $85^{2}$ \\
Female & 40 & $3^{\mathrm{I}}$ & 22 & $\mathrm{I} 9$ & 299 \\
Male & $4^{8}$ & $6 \mathrm{o}$ & $4^{2}$ & 37 & $\mathrm{I}, 553$ \\
Gentleman & $3^{8}$ & 43 & 43 & 36 & 42 \\
Yeoman & $5^{\mathrm{I}}$ & 83 & 65 & 49 & 206 \\
Husbandman & 54 & 79 & $3^{8}$ & 33 & 104 \\
Agricultural & 55 & $9^{\mathrm{I}}$ & 54 & 46 & 867 \\
Crafts & 59 & $5^{8}$ & 49 & 43 & 326 \\
Waged & 43 & $5^{2}$ & 26 & 29 & 42 \\
\hline \hline
\end{tabular}

Source: CKS, Archdeaconry Court of Canterbury probate inventories. For methods used for sampling and analysis see Mark Overton, Jane Whittle, Darron Dean and Andrew Hann, Production and Consumption in English Households, I600-I750 (Abingdon, 2004), 28-3I, 34-9, I8I-4.

baking and brewing equipment - would be more likely to contain female servants. Only nine households had clear evidence of all four of these activities, and of these only four employed female servants compared to 65 per cent of the whole sample. Of households with servants, 40 per cent had spinning wheels, and 69 per cent of these households did contain a female servant. However, servant-employing households with female servants and no spinning wheels were nearly twice as common as those with wheels and female servants. The majority ( 72 per cent) of households with servants had milk cows or 'kine', although none had more than ten cows. Yet households without cows were slightly more likely to contain female servants, and servant-employing households with three or more milk cows were less likely to employ a female servant than those with just one or two cows. ${ }^{43}$

More light is shed on these matters by a wider survey of probate inventories. Table 5 draws evidence from a large sample of Kent inventories from the first half of the seventeenth century. ${ }^{44}$ Spinning, dairying, baking and brewing were identified from equipment owned,

\footnotetext{
${ }^{43}$ The calculations for spinning and milk cows assume that households with servants of unspecified gender contained female servants. There were thirty-two households with three or more cows, of which twenty-two had female servants (69 per cent), fifteen households had one or two cows, of which fourteen had female servants (93 per cent).

${ }^{44}$ This data was collected as part of an earlier project, the results of which are published in Overton et al., Production and Consumption. See 29-3I for details of the Kent inventory sample. Only those dating from I6oo to I649 were used in this analysis.
} 
such as brewing vats and spinning wheels, and from specialist rooms, such as dairies or bake-houses..$^{45}$ As ever, this evidence needs to be treated carefully. Activities go unrecorded when they relied only on very cheap or non-specific equipment, or on equipment that was not owned by the user. Distaffs for spinning were rarely listed because they were so cheap, although spinning wheels were reliably recorded. Milk cows, milk pails, butter churns, kneading troughs and brewing vats are recorded; but, for instance, if a woman produced soft cheese or butter with non-specialist equipment having leased a cow, or baked non-wheat bread on a stone by the fire, her activities leave no record. Nevertheless, as long as we bear in mind the fact that non-recording could indicate small-scale, lower-quality production rather than no production, the data relate some important points about women's work.

Evidence of spinning, dairying, brewing and baking on a significant level was far from universal. Goods relating to these activities were more common in inventories for men than inventories for women. This is not because men undertook these activities: most male inventories relate to the households of married men which contained women, while 'female inventories' were left by widows and unmarried women, some of whose collections of goods did not always relate to a full household, but rather the possessions of someone who lived within a larger household. Status designations given in the inventory heading, such as gentleman, yeoman and husbandman, allow the inventories to be ranked very roughly in order of wealth. Yeomen's households were the most likely to carry out all these activities except spinning, which was slightly more common in the households of husbandmen. Occupational designations, of agriculture on a commercial scale, crafts and wage earning, were attributed from evidence within the inventory..$^{4}$ Dairying, as would be expected, was more common in households involved in commercial agriculture, but surprisingly common in craft and waged households. The waged sample is very small, but does hint at an important pattern of production, with such households being the least likely to brew and bake. Spinning was the activity least sensitive to differences of status, occupation or gender of the inventoried person, but many households show no evidence of this form of women's work, so often portrayed as universal.

\section{By-employment}

The realisation that various archetypal forms of women's work were not universal in this period is not entirely new. Shammas noted a similar pattern in another large sample of rural English inventories, dating

\footnotetext{
${ }^{45}$ Ibid., I8I-4.

${ }^{46}$ For methodology see ibid., 34-42.
} 
from $1550-1650 .{ }^{47}$ She was concerned with measuring the extent of home-based production, rather than examining patterns of work, and saw this as evidence of proletarianisation among poorer households. Viewed from the opposite perspective, it could also be seen as evidence of commercialisation. That not all households contained women who spun, brewed, baked and made butter and cheese implies that items made in this way were purchased, and that other households or businesses produced these items for sale. The scale of production, relationship of each activity to the market and how it changed over time requires investigation, as well as the gender of workers. Further, given the variations in the incidence of these types of work, elements of women's work such as dairying, spinning, brewing and baking should not be regarded as a single occupation of 'women's work'. Each had a degree of independence. Nor is dairying integral to other types of farming, or spinning necessarily located in the same household as weaving. Commercial brewing and baking did not arise naturally out of the provisioning of a household, nor did provisioning a household necessarily require these activities to be carried out. So rather than assuming that women's work was uniform, and giving it a vague label such as 'domestic production', it is more helpful to regard these activities as different occupations and treat them as an element of rural by-employment. Women's activities are noted in existing studies of byemployment, but this has not always filtered into our understanding of women's work. For instance in her classic article Thirsk writes that when mining and pastoral farming were combined, the householder mined 'while his family attended to the land and animals', ${ }^{4}$ and Skipp notes that in the Forest of Arden, spinning 'was easily the area's most important domestic by-employment'. ${ }^{49}$ What neither historian spells out is that byemployment, in these cases, consisted of men and women specialising in different production activities in order to support the household.

Milking and dairying were among a small number of agricultural tasks that were exclusively female, as they had been in the medieval period, and would remain until the late eighteenth century..$^{50}$ Although by the seventeenth century there is evidence of 'dairyman' and 'cheeseman'

${ }^{47}$ Carole Shammas, The Pre-Industrial Consumer in England and America (Oxford, 1990), 20-40.

${ }^{48} \mathrm{~J}$ Joan Thirsk, 'Industries in the Countryside', in Essays in the Economic and Social History of Tudor and Stuart England in Honour of R. H. Tawney, ed. F. J. Fisher (Cambridge, I96r), 73.

${ }^{49}$ Victor Skipp, Crisis and Development: An Ecological Case Study of the Forest of Arden ${ }_{1570-1674}$ (Cambridge, 1978), 57 .

${ }^{50}$ B. M. S. Campbell, 'Commercial Dairy Production on Medieval English Demesnes: The Case of Norfolk', Anthropozoologica, I6 (1992), I07-I8; Christopher Dyer, 'Changes in Diet in the Later Middle Ages: The Case of Harvest Workers', Agricultural History Review, 26 (I988), 22; John Broad, 'Regional Perspectives and Variations in English Dairying, I6501850', in People, Landscape and Alternative Agriculture: Essays for Joan Thirsk, ed. R. W. Hoyle (British Agricultural History Society, 2004), 93-II2. 
being given as male occupations, it seems likely that these were men who managed dairy farms and marketed dairy produce, rather than doing the milking, or making butter and cheese themselves. Strong cultural taboos meant that only women worked directly with milk..$^{{ }^{1}}$ The best-quality butter and cheese produced for the market was made largely in the wealthy farming households of yeomen and gentry, which had the space and equipment to do so. As many other households did not produce their own dairy products, or could only make products of low quality which needed to be eaten fresh, much of the dairy products made by women on the larger farms must have been destined for sale. The farms of Robert Loder, Henry Best, the Tokes of Kent and the Willoughbys in Devon all produced more dairy products than they needed, and sold the excess..$^{52}$

By the eighteenth century 'it was generally agreed that one woman could milk and process the liquid of up to ten cows' ${ }^{53}$ Bartholomew Dowe's A Dairie Booke for Good Husewives, published in I588, purports to describe the advanced methods of Suffolk dairying, which he observed his mother practising, to a woman from Hampshire, where he was then living. Dowe claims that on a large Suffolk dairy farm, each female servant could care for and milk twenty cows: 'for every score of kine a maid'. The Hampshire woman replies, 'eight or nine kine is enough for one maide servaunt to milke in this Countrie'. ${ }^{54}$ We might dismiss Dowe's claim for Suffolk as hyperbole, if it were not for the fact that his mother's dairy enterprise can almost certainly be traced to Sibton Abbey in east

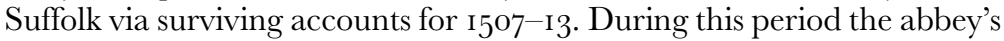
dairy was managed by one Katherine Dowe, the name of Bartholomew's mother. In I509, the dairy had sixty-three cows, and the abbey employed Katherine and three maids to milk them, make butter and cheese, as well as keeping pigs and poultry and making linen: which works out at fifteen or sixteen cows per worker. ${ }^{55}$ Kent inventories do not record dairying on this scale. Of the I,852 inventories sampled, those mentioning milk cows had an average of three per household in the period $1600-49 \cdot{ }^{56}$ The maximum number owned by one household in this period was thirty-four, but this was an isolated case; even the larger herds rarely contained more than ten

${ }^{51}$ Deborah Valenze, 'The Art of Women and the Business of Men: Women's Work and the Dairy Industry c. I740-I840', Past and Present, I30 (I99I), I42-69.

${ }^{52}$ See Table 2. Robert Loder, ed. Fussell, I53-4; Henry Best, ed. Woodward, I72 and I75; The Account Book of a Kentish Estate I6I6-I704, ed. Eleanor C. Lodge (Oxford, I927), 8I; Devon Household Accounts, I627-59, Part I, ed. Todd Gray (Devon and Cornwall Record Society New Series 38, I995), $15 \mathrm{I}-63$.

${ }^{53}$ Nicola Verdon, “ ". . Subjects Deserving of the Highest Praise”: Farmers' Wives and the Farm Economy in England, c. I700-I850', Agricultural History Review, 5I (2003), 29.

${ }^{54}$ Bartholomew Dowe, A Dairie Booke for Good Huswives (I588), sig. A3r.

55 The Sibton Abbey Estates: Select Documents 1325-1509, ed. A. H. Denney (Suffolk Records Society II, I960), 38-9 and I42.

${ }^{5}$ Sample as used in Table 5 , above. 
cows. Herds of this size could be managed by one woman, as long as she was not overburdened with other types of work. This explains the lack of direct correlation between the employment of female servants and dairying in the Kent inventories cross-referenced with accounts. Small dairy herds did not necessarily require female labour beyond that of the housewife. Farmers who produced butter and cheese commercially, even if this was only a small part of their farming enterprise, such as Loder, Best, Toke and Willoughby, employed at least one female servant.

In the medieval period ale was brewed and sold by women from poor, middling and wealthy households. Ale did not keep well, so it was more economical to make a large batch and then sell much of it to one's neighbours, and thus circulate the task of brewing around the community. In the fifteenth and sixteenth centuries brewing became increasingly concentrated and professionalised, and simultaneously a male occupation. The innovation of beer brewed with hops prolonged the time the beverage could be stored before sale, accentuating these trends. In southern and eastern England where wheat bread was consumed, baking had been a specialised male occupation by at least the fourteenth century. Once brewing became specialised particular households began to take up 'victualing': baking, brewing and running an ale-house. Small towns had a number of such victualers whose products were peddled to households in nearby communities. Women were certainly still involved in these activities, in partnership with their husbands and as peddlers, but brewing had ceased to be the female preserve it once was. ${ }^{57}$ Inventories show that by the seventeenth century households with the space and equipment to do so produced beer and bread at home, catering for their staff of servants and other workers as well as the family. ${ }^{8}$ However, excess bread or beer from these households was not sold on in the same way as dairy products. Poorer households which lacked the necessary equipment, and households in which women were too busy to brew and bake, now relied on specialist victualers and peddlers.

Spinning, although universally female, was not carried out by all women. ${ }^{59}$ The identification of spinning in probate inventories relies on the presence of a spinning wheel, or on the listing of raw wool or flax together with finished yarn. Kent inventories indicate that although spinning was found in households of all levels of wealth, it was not evenly spread geographically: the proportion of households showing evidence of

${ }^{57}$ Judith M. Bennett, Ale, Beer and Brewsters in England: Women's Work in a Changing World, I300-I60o (Oxford, I996); Mavis E. Mate, Daughters, Wives and Widowes after the Black Death: Women in Sussex, 1350-I525 (Woodbridge, 1998), 59-71.

${ }^{5}$ See Table 5, above; also Shammas, The Pre-Industrial Consumer, 35 and 39.

${ }^{59}$ Male 'spinners' were middlemen who purchased and sold on yarn: Alice Clark, Working Life of Women in the Seventeenth Century (1919), II3. 
spinning varied a great deal between communities. Out of twenty-eight Kent communities surveyed for the period I60o-49, ten revealed evidence of spinning in more than $5^{\circ}$ per cent of inventories, although in no community did the proportion exceed $5^{8}$ per cent. ${ }^{60}$ On the other hand, in five communities, including Canterbury, the proportion was under 30 per cent: Milton had the lowest incidence at i7 per cent. Interestingly, there was no clear pattern of geographical distribution. As might be expected, communities such as Goudhurst, in the Wealden broadcloth area, showed a high incidence of spinning, but so did Minster in Thanet, in the north-east of the county, perhaps due to its proximity to Sandwich, which specialised in the New Draperies. ${ }^{61}$

In The Ballad of the Tyrannical Husband's fictional account of women's work, the housewife wove cloth as well as spinning the yarn, producing clothing for her family from raw materials. In the late fourteenth and fifteenth centuries, Goldberg found that female weavers were commonly found in rural areas and small towns as part of the cloth trade, as well as occasionally in larger cities. ${ }^{62}$ The exclusion of women from weaving as a specialist trade in the late fifteenth and sixteenth centuries is documented by Clark. ${ }^{6}$ Probate inventories from the first half of the seventeenth century show that loom ownership was quite rare, and very largely confined to specialist cloth-producing areas. Not only had women been excluded from professional weaving, but weaving for home use seems also to have died out. Thus, in the sixteenth and seventeenth centuries, women who spun did so as a cash-earning activity, as part of the commercial cloth production system. Only a minority of spinners lived in households where weaving was also carried out. Spinning is more laborious than weaving: Zell's figures for Kent broadcloth suggest six spinners were needed to supply each weaver in the late sixteenth century, if they all worked full time, which was unlikely. ${ }^{64}$ Spinning was notoriously poorly paid: Clark thought full-time spinning could just support a woman if she worked on high-quality yarns, as long as she had no dependants. ${ }^{6}$ Kent inventories indicate that 44 per cent of widows had spinning equipment. Somewhat ironically, the same was true of only 26 per cent of spinsters, while over 50 per cent of husbandmen's and

\footnotetext{
${ }^{60}$ The twenty-eight communities are listed and mapped in Overton et al., Production and Consumption, 3I.

${ }^{61}$ C. W. Chalklin, Seventeenth Century Kent: A Social and Economic History (1965), 124-6.

${ }^{62}$ Goldberg, Women, Work and Life Cycle, 97-9, I20 and I46-7. $^{6}$.

${ }^{63}$ Clark, Working Life of Women, I02-6.

${ }^{64}$ It took eighty-five to ninety days to spin enough yarn for one broadcloth and fourteen days to weave it: Michael Zell, Industry in the Countryside: Wealden Society in the Sixteenth Century (Cambridge, I994), I66 and I76. Sara Mendelson and Patricia Crawford, Women in Early Modern England I550-I720 (Oxford, I998), 27I, suggest four spinners to each weaver in the cloth industry more generally.

${ }^{65}$ Clark, Working Life of Women, II5 (although her evidence is mostly from I650 to I750).
} 
yeomen's inventories record evidence of spinning. ${ }^{66}$ In Kent at least, it appears that in the early seventeenth century spinning was rarely a full-time occupation undertaken by independent women, probably because earnings were so low. Instead it was a money-earning activity that housewives, widows and female servants worked on when they were free from other tasks. Trends in spinning in the century after i650 show that decline in Kent's cloth industry led to a decline in the ownership of spinning wheels, and thus of spinning as a female by-employment. ${ }^{67}$

\section{Conclusion}

This brief summary perhaps serves best to indicate the need for more research on these topics, following the example of Bennett's excellent study of brewing. ${ }^{68}$ The lack of detailed research on women's work is often excused by lack of documentation. Yet some of the most common and well-known types of document that survive for the mid-fifteenth to mid-seventeenth centuries, wills and inventories, together with probate accounts, contain a great deal of evidence about women's work. They are not straightforward to interpret, and need to be used in conjunction with other types of sources, but they do provide a means to getting beyond a static, oversimplified view of what female servants and housewives did in rural households. Women's work varied regionally and according to a household's wealth. Different occupations were commercialised in different ways: women's work was not isolated from the market. Some forms of women's work generated income through sale of products; others were part of a larger profit-orientated household structure, such as the wives and female servants on yeomen's farms who processed food, cooked and cleaned for paid employees as well as family members. ${ }^{69}$ Housewives and female servants also spent time caring for young children, a task often omitted in descriptions of women's work.

The employment of female servants demonstrates that on a practical level at least, women's work was valued: why else bother to pay for an extra woman's labour? Yeomen's households normally employed one or two female servants, but might employ as many as six male servants. The occupations of female servants on these farms remained small scale: malting, brewing and baking became male professions, carried out away from the farm when undertaken on a large scale, while spinning was not profitable enough for full-time work in these households. In contrast,

\footnotetext{
${ }^{66}$ The low rate for spinsters does not mean that unmarried women were least likely to spin, simply that they did not spin on their own equipment: they were not independent spinners.

${ }^{67}$ Overton et al., Production and Consumption, 48.

${ }^{68}$ Bennett, Ale, Beer and Brewsters.

${ }^{69}$ Using family here in its modern sense, to mean those related to the household head and resident.
} 
the male-dominated occupations on such farms, arable and livestock agriculture, were expanding in scale over the period. Commercial dairy farming is one possible exception, but most dairies remained small enough for one woman to manage. Katherine Dowe's subcontracted dairy in Suffolk was unusual.

A large proportion of female servants in rural England were employed as lone servants in the less wealthy households of husbandmen. The irony is that these smaller farms were less likely to carry out all of the four female occupations we have measured, so appear to have had less work for women. Yet a close analysis of probate inventories and accounts of twenty-six Kent households that employed only one female servant reveal that there was work to be done. Of the householders represented, seven were widows or widowers, at least five of whom were elderly; eight had young children under six years old; seventeen had at least one cow that needed to be milked; eight had one or more spinning wheels. Each household employing one female servant had a unique combination of activities normally allotted to women: Thomas Willard of Benenden with goods worth $£ 84$ was a married victualer whose household brewed and baked as well as selling the products. Roger Baker of Chartham with goods worth only $£_{2} 6$ was also married and his household kept a cow, geese and hens, spun linen and wool, grew hemp and baked bread. John Garrett of Goudhurst, worth $£ 29$, was married with six children aged between two and sixteen: his household made malt and cheese. Gabriel Morland of Wye worth $£ 5^{8}$ was widowed and elderly, a faded gentleman with a house full of stuff, much of it old, and one female servant to run it. $^{70}$ The servants in these households 'did the things that must indeed be done', a mixture of farm work, housework and caring for the young and old, reflecting the varied work patterns of maid servants and housewives across rural England.

${ }^{70}$ CKS, Archdeaconry Court of Canterbury probate documents: Thomas Willard inventory I0.36.326 (I6og), account PRC2/ I6/200 (I6I2); Roger Baker inventory I0.33.223 (I6o9), account PRC2/I5/30 (I6Io); John Garrett inventory I0.44.5 (I6II), account $\mathrm{PRC}_{2}$ /18/66 (I6I3) and Gabrael Morland inventory I0.49.I96 (I6I6), account PRC2/22/35 (I6I9). 